\title{
A community-based intervention approach to control disease outbreaks and climate-related deaths in communally raised goat kids in the Eastern Cape Province, South Africa
}

\author{
Mhlangabezi Slayi ( $\square$ mslayi@ufh.ac.za) \\ University of Fort Hare \\ Leocadia Zhou \\ University of Fort Hare \\ Thobela Louis Tyasi \\ University of Limpopo \\ Ishmael Jaja \\ University of Fort Hare
}

\section{Research Article}

Keywords: Animal health, community engagement, diseases, extension services, intervention model, resource-constrained farmers, South Africa

Posted Date: November 8th, 2021

DOI: https://doi.org/10.21203/rs.3.rs-985313/v1

License: (c) (i) This work is licensed under a Creative Commons Attribution 4.0 International License. Read Full License

Version of Record: A version of this preprint was published at Tropical Animal Health and Production on March 22nd, 2022. See the published version at https://doi.org/10.1007/s11250-022-03143-5. 


\section{Abstract}

A community-based intervention study was conducted, from April 2017 to March 2019, on 512 kids born from flocks of 30 purposively selected households in ten villages within Alice district of the Eastern Cape Province, South Africa. The study aimed to examine the effectiveness of combined efforts from the research team and farmers to control disease outbreaks and climate change-related deaths. Diseases and climate-related deaths were diagnosed based on clinical signs, laboratory results and relevant necropsy records. One hundred and thirty two kids died in year-1, accounting for $56.17 \%$, while sixty two kids died in year-2, accounting $22.38 \%$ for mortality rate. Seasonal prevalence of helminthosis $(P=0.0058)$, diarrhea $(P=0.0056)$ and acquired injuries $(\mathrm{P}=0.0044)$ to predatory attacks predisposed to various causes of mortalities. Tick loads were only recorded $(\mathrm{P}=0.0069)$ to kids older than 90 days. Death due to heartwater $(\mathrm{P}=<0.0001)$ was prevalent to kids older than 90 days during hot-dry and hot-wet seasons. Gastrointestinal problems $(P=0.0024)$ were recorded throughout the year irrespective $(P=0.0080)$ of the age group. Wound-related deaths were enrolled throughout $(P=$ $0.0042)$ the four seasons. Kids younger than 45 days died from pneumonia $(P=0.0003)$ and hypothermia $(P=0.0058)$ during cold-dry months. Does in parity 1 were the only victims to abortions $(P=0.0002)$, stillbirths $(P=<0.0001)$ and dystocia $(P=<0.0001)$. A decline in kid mortalities in year-2 indicates that the approach was a moderate success. However, this requires further consideration regarding affordability and accessibility prior to implementing the intervention model at a broader scale.

\section{Introduction}

Goats are the most widespread livestock species in South African farming communities (Dube et al., 2016). A high proportion of them is found in rural areas of the Eastern Cape Province (Idamokoro \& Masika, 2017). More than three-quarters of the goat population in the province is reared under traditional farming systems (Slayi et al., 2014). Goats kept in rural communities are owned mainly by resource-constrained farmers who barely afford conventional drugs and solely rely on traditional medicine to cure various ailments and on natural resources as a source of feed and access to drinking water (Khandoker et al., 2018). Communal farmers prefer to rear goats for their low cost of production, prolificacy, and excellent adaptive capacity to warm environment, dynamic feeding behaviour, and fast reproduction cycle (Sebei et al., 2004). Goat rearing play a prominent role in the livelihoods of many small and marginal farmers, including landless labourers (Faruque et al., 2017). Socially, goats serve as a source of protein in human diets during festival gatherings and provide good and stable source of income, especially for the underprivileged people in rural areas (Abiola \& Onwuka, 2021; Wachida et al., 2018). The degree to which goats survive to marketable age is one of the prominent indicators for efficient goat production (Mhlanga et al., 2018). Evidence show that goats serve as saving and living banks for the financially disadvantaged rural people since they can easily be converted into cash when a need arise by virtue of their ready market demand (Moni \& Samad, 2019). In addition, goat rearing has been modelled by various government and non-governmental research institutions all over the world to mitigate rural poverty (Yasmin et al., 2020).

Annually, a high number of goats is sold during the winter and summer months as well as during Easter holidays of the year where most of the traditional ceremonies and rituals are likely to be performed (Idamokoro \& Masika, 2017). South Africa has substantial potential for animal production (Donkin \& Boyazoglu, 2004), and several reports have shown a growing demand for domestic goat products (Dube et al., 2016). Increased consumer demand could be attributed to popularised health benefits of goat products, as recommended by many researchers and health awareness professionals (Diriba \& Kebede, 2020). Among those health benefits is that health conscious consumer groups accept meat and dairy products derived from goat milk due to its low contents of allergens known to be responsible for several health risks in humans (Oyeyemi \& Akusu, 2021). Despite this growing consumer demand and acceptance of goat products, there seem to be endless production hurdles impeding the marketing and availability of goat products, thus threatening the sustainability of the sector in South Africa(Slayi et al., 2014). Due to its overreliance on natural resources, goat production in the country is highly vulnerable to various climatic shocks including feed unavailability and disease outbreaks (Snyman, 2010). Different constraints and concerns have been highlighted by many researchers in the past of which diseases remain the major setback towards improved goat production, reproduction and marketing in rural communities in the Eastern Cape Province (Donkin \& Boyazoglu, 2004; Slayi et al., 2014). Globally, diseases of various origins (bacterial, viral, parasitic, etc.) continue to be among the leading causes for poor goat health and production in rural communities (Alemnew et al., 2020; Ebozoje \& Ngere, 2021), account for 40-60\% losses in South Africa. Parasitic diseases play a detrimental role in hampering small ruminant production leading to serious production and financial losses throughout the world (Fthenakis \& Papadopoulos, 2018). For instance, the annual economic loss due to diseases, mortality and reduced reproductive performance was estimated at 150 million United States Dollar currency in Ethiopia (Abraham et al., 2018; Alula et al., 2014).

In an attempt to counter the problems mentioned above, Boer goat and other indigenous breeds such as the Nguni and Xhosa lop-eared goats are the most preferred and dominant breeds in rural farming communities of South Africa (Dube et al., 2016). Large proportions of Nguni and Boer goat breeds could be attributed to government efforts to upgrade the genetic makeup and productivity of communal goat flocks by distributing them to farmers in rural communities throughout the country (Sebei et al., 2004). Such government endeavours involve the distribution of 2 to 3 Boer goat bucks per village and the bucks are taken back to the government institutions after 3 to 5 years to avoid inbreeding depression (Abraham et al., 2018). Moreover, apparent evidence accrued through extensive studies suggests that local genotypes such as Nguni, Boer goat and their crosses are highly resistant to endemic diseases and thrive well in harsh environmental conditions (Snyman, 2010). Despite all these efforts, the ongoing increase in disease prevalence and kid mortalities due unknown causes, and climate change risks undermine the productive potential of village preserved goat flocks in the Eastern Cape Province of South Africa (Slayi et al., 2014).

Mortality rates of kids from birth to weaning is one of the prime effects on the viability of goat production efficiency in communal areas (Perumal et al., 2019; Yasmin et al., 2020), with kid mortality rates as high as $46.51 \%$ having been reported in various farming communities across South Africa (Sebei 
et al., 2004; Slayi et al., 2014). The untimely exits restrict the number of animals available for future replacement and impact the number of animals reaching marketable age (Chauhan et al., 2019). Increased kid mortality rate is sometimes attributed to genetic and environmental factors (Alemnew et al., 2020; Perumal et al., 2019). Insufficient milk production from the does remaining a major constraint directly linked to reduced total productivity. Among the factors contributing to postnatal kid mortality are birth type (single, twins or triplets), season, age, sex, birth weight, and difficult or prolonged birth weight (Robertson et al., 2020). In a study conducted by Slayi et al. (2014), it was noted that farmers are quite aware of some of the leading causes of kid mortalities in communal goat flocks. However, farmers' insufficient attempts to validate allegations hampers suboptimal performance and the ability to develop and apply management interventions to control disease prevalence and climate change-related deaths in rural communities. Apart from insufficient literature describing actual causes of mortality, inadequate support from the government with respect to initiation and facilitation of control programmes or funding of research on diseases and climatic-related deaths affecting adult goats and their kids still poses another challenge to communal goat farming. Any attempt to ensure kids' survival is bound to increase the number of marketable animals, which later influences the viability of goat enterprise through improved production efficiency and good financial returns. Therefore, this community-based intervention project was conducted to control diseases and climatic-related deaths in communally raised goat kids by specifically considering their associated risk factors in some resource-constrained communities in the Eastern Cape Province, South Africa.

\section{Materials And Methods}

\subsection{Description of experimental site}

A community-based intervention trial to control diseases and climate-related deaths amongst village- owned goat kids was conducted in ten villages located within Alice district in the Eastern Cape Province of South Africa from April, 2017 to March, 2019. The Eastern Cape Province is made up of thirty seven districts. Alice district falls under Raymond Mhlaba Local Municipality in the Eastern Cape Province. The municipality covers 3725 square kilometers, has an average of 43 people per square $\mathrm{km}$ or 0.43 people per hectare, and is made up of 21 wards and 194 villages. Alice district is about $21.97 \mathrm{~km}^{2}$ wide with an altitude of $522 \mathrm{~m}$ above sea level and is located $32^{\circ} 47^{\prime} \mathrm{S} 26^{\circ} 50^{\prime} \mathrm{E}$. The site is situated $80 \mathrm{~km}$ inland from the Eastern Cape coast line. Livestock production is the lifeblood of this resource-constrained local population keeping indigenous goat breeds as the most preferred livestock species in the area. The region is sparsely populated and fragile to climate variability experiencing extremes of drought and floods. Animals in the study area rely on natural pastures as a source of feed. The climate of the study area is characterized by a slightly hot summer, high humidity all the yearround, and inconsistent rainfall (annual average rainfall of $473.2 \mathrm{~mm}$ ), which is received during November to April. Averagely, the site recorded a daily maximum temperature of $25.8^{\circ} \mathrm{C}$, and a minimum temperature of $11.2^{\circ} \mathrm{C}$. Humidity is high throughout the year, the average being $72.1 \%$. The study area is located in a hot, humid zone having four distinct seasons, viz., post-rainy (March to May), cold-dry (June to August), hot-dry (September to November), and hot-wet (December to February). The area lies in a lowland characterised by steep, isolated mountains and the veld type is predominant of Bhisho Thornveld. Several trees characterise the vegetation in the region, including shrubs, and grass species with Acacia karroo, Themeda triandra, Panicum maximum, Digitaria eriantha, Eragrostis spp., Cynodon dactylon and Pennisetum clandestinum being the dominant plant species. Soils are extremely heterogenous but are predominantly sedimentary (sand and mudstones) with some variation when intrusions of igneous rock (doleritic dykes and sheets) result in red soils occurring in some areas. Figure 1 shows the location of the villages used as sites during the field trial period.

\subsection{Ethical consideration and process of mobilizing farmers}

Before entering the communities for actual data collection, a prior informed consent was obtained from the Research Ethics Committee of the University of Fort Hare (MAP021SSLA01). The quality of data to be collected in a participatory manner in traditional communities largely depends on the genuine cooperation of the community. This genuine cooperation stipulates clarification and sensitization of the community on the objectives, intentions, and use of possible outcomes of the study. Accordingly, a series of community meetings were organized at each village before the commencement of actual field work. The headmen in each village were contacted and briefed on the rationale for conducting the meetings. This was done to explain in detail the procedure of the project, including its objectives and outcomes. The meetings were then called by and conducted in the presence of the headmen.

\subsection{Sampling of village participants and management of experimental animals}

There are thirty seven district municipalities in the Eastern Cape Province of South Africa. From the existing district municipalities in the province, Alice district was purposively chosen because of its rich history of being known as a livestock-based community with high goat population in the province. Villages that participated in the study were selected using a $30 \%$ random sampling criterion. Ten villages from the total number of 30 villages were chosen to participate in the study. The selected villages had the advantage of being close to the research team, allowing frequent visits during data collection period. Villages of interest were Skolweni (Sheshegu), Lalini (Sheshegu), Phumlani, Guburha, Khayamnandi, Lenge, Skolweni (Gaga), Komkhulu, Nomaqamba and Ncerha-Skhweyiya. Three flock owners were selected to participate in the study using a snow-ball sampling technique from each of the selected villages. In this way, thirty farmers were selected from 10 villages which constituted the sample. The method was chosen because it only selected farmers who rear goats as adjuncts to their main occupation and have a history of being known to experience high kid mortality rates in their flocks. This was the basis of the study. During the 2 year trial period, a total of number of 512 goat kids were subjects in the study site. Newly born kids were weighed a few minutes after birth and housed separately in animal shelters for three months before joining the flock. The ages of the kids considered were from birth to twelve months; that is, animals closely monitored from birth until they died or were 1 year old or the study ended, whichever came first. In all, kids older than 1 year were no longer followed or censored at the end the study. All the kids born during the research period were ear-tagged to ensure easy identification during field visits and data gathering during the trial. During the day, flocks from all the participating 
villages browse (from 7am to $4 \mathrm{pm}$ ) on communal grazing areas dominated by open grassland. There was virtually no habit of supplementation of any group of goats, including nursing and pregnant does. Goats access drinking water from nearby streams and dams. The goats reproduce year-round without a controlled breeding program. During the first year of the study, flock owners were responsible for daily kid care and administering treatment of illnesses independently without any experimental treatments or interventions applied by the research team. In the second year of the trial, the flock health management was maintained through regular follow-up by the research team and treatment of clinical cases. Regular deworming based on coprological examination for internal parasite infestation was done. Regular spray for external parasites and vaccination for major bacterial and viral small ruminant diseases such as pneumonia, coccidiosis and other infectious diseases prevalent in the area was done.

\subsection{Data collection and research team participation}

Diseases and climate related deaths were documented over a period of two years (April 2017 to March 2019). Diagnosis of diseases and climate related deaths was based on previous history recorded from farmers, clinical signs and laboratory findings. Data gathering was made possible through close cooperation between the farmers and the research team. To ensure the consistent commitment of farmers to the project and achieve the study objectives, regular flock visits were done throughout the follow-up period, and prior arrangements were made with the farmers. Data collected during the first year of the trial was used as baseline information to measure and understand the severity of the study problem. For effective measurements and accurate results, farmers were allowed to continue managing their animals without any interference from the research team regarding veterinary assistance and advice. While in the second year of the trial, there was full cooperation of the research team and farmers through the supply and distribution of veterinary drugs and advisory services to improve survival rate of goat kids. Prior to collecting data, farmers voluntarily committed to informing the research team whenever there is a new born kid in the flock. This included calling the research team whenever there was a sick or dead kid. Upon arrival, the team recorded the date of birth and birth weights were recorded. Whenever there was a sick or dead kid in their flock, farmers contacted the research team. The cause of illness or death was determined from the clinical history, clinical observations, laboratory findings, and relevant necropsy findings. In some cases, confirmation was based on health treatment records or weighing records collected by the research team during routine farm visits. Farmers were asked to submit dead kids for post-mortem examination; when possible, the farmer also provided a clinical history and the suspected cause of death. If the necropsy could not be performed within 24 hours of death, the carcass was refrigerated at $4^{\circ} \mathrm{C}$; otherwise, it was frozen at $-20^{\circ} \mathrm{C}$ and thawed for 1 day before the examination. A systematic inspection of all thoracic and abdominal organs, tissues, joints, umbilicus, skull, and brain was completed by a veterinarian. The cause of death was determined based on any gross pathological examinations or abnormal findings observed. Where necropsy did not reveal the cause of death, tissues from organs mentioned previously were fixed in 10 percent formalin, processed by a routine paraffin technique, sectioned at 5 micro meters. Analysis of the obtained specimens were processed by the research team at Grahamstown Veterinary laboratory. Farmers consistently cooperated with the research team throughout the research period. The sick and dead kids collected were grouped based on age (0 - 45 days, 46 - 90 days, 91- 135 days and older than 136 days) to determine morbidity and mortality rates among various groups. Also, the time of exposure was grouped into seasons (post-rainy (March to May), cold-dry (June to August), hot-dry (September to November) and hot-wet (December to February). Reproductive losses such as abortion, stillbirths and dystocia were further grouped according to the parity of the doe (1st, 2nd, 3rd and 4th ). Among various diseases the proportional morbidity/mortality was calculated by the formula:

$$
\begin{aligned}
\operatorname{MorbidityRate}(P) & =\frac{\text { Numberofkidsaffectedbyaspecificdisease }}{\text { Totalnumberofkidsaffectedbyallthediseases }} X 100 \\
\operatorname{MortalityRate}(P) & =\frac{\text { Numberofkidsdiedduetoaspecificdisease }}{\text { Totalnumberofkidsdiedduetoallthediseases }} X 100
\end{aligned}
$$

\subsection{Statistical analysis}

Recorded data were entered in an excel spread-sheet as a database and used to analyze different attributable factors. The variables considered for the identified causes of morbidity and mortality were different climatic seasons of the year and mortality of kids to specific age group (birth to 45 days, 46 to 90 days, 91 to 135 days, and older than 136 days). Parity of the doe (1st, 2nd, 3rd, and 4th ) was also used as a variable for reproductive losses. The data were analysed by Statistical Package for Social Science (SPSS) software 20.0 version, with goat kid as a unit of interest. Descriptive statistics were used to summarise the data. Chi-square $(\chi 2)$ test was applied to test the existence of association and to see the level of significance between observed causes of mortality and associated risk factors, respectively, with significant difference being accepted at $\mathrm{P}<0.05$.

\section{Results}

A total of 512 kids were born during the 2-year trial period, with 235 births enrolled in the first year and 277 were conceived in the second year of the study. One hundred and thirty two kids died in the first year of the research period, accounting for $56.17 \%$, while 62 (22.38\%) kids died in the second year of the trial. Death of kids was due to several health problems identified on sick animals and others being further diagnosed on post mortem records. Table 1 summarizes several infections and parasites contributing to the morbidity of the kids. Year- 1 results indicate that helminthosis ( $P=0.0058)$ prevalence significantly occurred throughout the year except during cold-dry season. Kids belonging to age group (91-135 days) and those older than 136 days were at highly $(P=0.0019)$ susceptible to helminth infestation. On the other hand, year- 2 results show that season type nolonger ( $P=0.2588)$ had an effect on helminth infestation, and the rate was lower than those obtained in year-1. Older kids belonging to ( $91-135$ days) and (older than 136 day) age group remained at higher $(P=0.0278)$ risk to helminth infestation. Tick prevalence was consistently detected throughout the year, irrespective of the period of the trial. Year- $1(P=0.0069)$ and year-2 $(P=0.0004)$ results showed that high tick loads were observed in all the age groups except on kids younger than 40 days. 
Post-rainy season in year- 1 had a higher $(P=0.0056)$ prevalence of diarrhea than other seasons, with kids younger $(P=0.0003)$ than 40 days as the main victims of the condition compared to the age groups. Kids younger than 40 days remained $(P=0.0180)$ susceptible to diarrhea even after applying intervention strategies by the research team. Year-1 results show that kids belonging to age groups (0-40 days) and (41-90 days) were at higher risk $(P=0.006)$ of contracting contagious ecthyma. Footrot occurrence remained insignificantly low irrespective of the period of the trial. Man-made factors contributing to illnesses through injuries were recorded and presented in Table 2. It was noted that predatory attacks in year- 1 consistently ( $P=0.0044)$ occurred throughout the trial period irrespective of the season. Year-1 results had a lower prevalence of predatory attacks irrespective of the year's age group $(\mathrm{P}=0.1510)$ or season $(\mathrm{P}=0.2776)$. Kids belonging to the two age groups ( $0-40$ days) and (41-90 days) were at higher risk of being knocked by moving cars in year- 1 of the trial. Several causes of kid mortality were recorded in the current study. Year- 1 and 2 prevalence of infectious diseases and management factors contributing to mortality in kids is presented in Table 3. During year-1, mortality due to gastrointestinal disorders were recorded throughout $(P=0.0024)$ the year except during post-rainy season. 
Table 1

Prevalence of infections and parasites contributing to morbidity in goat kids according to climatic season and age group

\begin{tabular}{|c|c|c|c|c|c|c|c|c|c|c|c|c|c|}
\hline & \multirow{2}{*}{$\begin{array}{l}\text { Type of } \\
\text { ailment }\end{array}$} & \multicolumn{4}{|l|}{ Season } & \multirow{2}{*}{$\begin{array}{l}\chi^{2} \\
\text { value }\end{array}$} & \multirow[t]{2}{*}{ P-value } & \multicolumn{4}{|c|}{ Age group (days) } & \multirow{2}{*}{$\begin{array}{l}\chi^{2} \\
\text { value }\end{array}$} & \multirow[t]{2}{*}{ P-value } \\
\hline & & $\begin{array}{l}\text { post- } \\
\text { rainy }\end{array}$ & $\begin{array}{l}\text { cold- } \\
\text { dry }\end{array}$ & hot-dry & $\begin{array}{l}\text { hot- } \\
\text { wet }\end{array}$ & & & $0-45$ & $46-90$ & $\begin{array}{l}91- \\
135\end{array}$ & $<136$ & & \\
\hline \multirow{15}{*}{$\begin{array}{l}\text { Year- } \\
1\end{array}$} & Helminthosis & & & & & & & & & & & & \\
\hline & Yes & 26.67 & 0.00 & 15.15 & 16.67 & \multirow[t]{2}{*}{12.54} & \multirow{2}{*}{$0.0058^{\star \star}$} & 0.00 & 3.13 & 25.00 & 23.33 & \multirow[t]{2}{*}{14.87} & \multirow[t]{2}{*}{$0.0019 * \star$} \\
\hline & None & 73.33 & 100.00 & 84.85 & 83.33 & & & 100.00 & 96.88 & 75.00 & 76.67 & & \\
\hline & \multicolumn{13}{|l|}{ Ticks } \\
\hline & Yes & 9.52 & 22.22 & 33.33 & 25.00 & \multirow[t]{2}{*}{6.49} & \multirow{2}{*}{$0.09^{n s}$} & 3.33 & 18.75 & 23.08 & 40.00 & \multirow[t]{2}{*}{12.16} & \multirow[t]{2}{*}{$0.0069 * \star$} \\
\hline & None & 90.48 & 77.78 & 66.67 & 75.00 & & & 96.67 & 81.25 & 76.92 & 60.00 & & \\
\hline & \multicolumn{13}{|l|}{ Diarrhea } \\
\hline & Yes & 50.00 & 22.22 & 18.18 & 20.83 & \multirow[t]{2}{*}{12.61} & \multirow{2}{*}{$0.0056^{\star \star}$} & 60.00 & 21.88 & 25.00 & 13.33 & \multirow[t]{2}{*}{18.71} & \multirow[t]{2}{*}{$0.0003^{\star \star}$} \\
\hline & None & 50.00 & 77.78 & 81.52 & 79.17 & & & 40.00 & 78.13 & 75.00 & 86.67 & & \\
\hline & \multicolumn{13}{|l|}{$\begin{array}{l}\text { Contagious } \\
\text { ecthyma }\end{array}$} \\
\hline & Yes & 21.43 & 8.89 & 3.03 & 12.50 & \multirow[t]{2}{*}{6.55} & \multirow[t]{2}{*}{$0.0875^{\mathrm{ns}}$} & 13.33 & 31.25 & 5.77 & 0.00 & \multirow[t]{2}{*}{17.52} & $0.006^{\star \star}$ \\
\hline & None & 78.57 & 91.11 & 96.97 & 87.50 & & & 86.67 & 68.75 & 68.75 & 100.00 & & \\
\hline & Footrot & & & & & & & & & & & & \\
\hline & Yes & 0.00 & 8.89 & 6.06 & 0.00 & 5.68 & $0.1283^{\mathrm{ns}}$ & 0.00 & 0.00 & 7.69 & 6.67 & 4.78 & $0.1883^{\mathrm{ns}}$ \\
\hline & None & 100.00 & 91.11 & 93.94 & 100.00 & & & 100.00 & 100.00 & 92.31 & 93.33 & & \\
\hline Year- & Helminthosis & & & & & & & & & & & & \\
\hline & Yes & 0.00 & 15.79 & 10.53 & 18.18 & 4.03 & $0.2588^{\mathrm{ns}}$ & 0.00 & 0.00 & 22.73 & 18.18 & 9.11 & $0.0278^{*}$ \\
\hline & None & 100.00 & 84.21 & 89.47 & 81.82 & & & 100.00 & 100.00 & 77.27 & 81.82 & & \\
\hline & Ticks & & & & & & & & & & & & \\
\hline & Yes & 9.09 & 26.32 & 36.84 & 45.45 & 6.45 & $0.0915^{\mathrm{ns}}$ & 0.00 & 16.00 & 31.82 & 72.73 & 18.37 & $0.0004^{\star \star}$ \\
\hline & None & 90.91 & 73.68 & 63.16 & 54.55 & & & 100.00 & 84.00 & 68.18 & 27.27 & & \\
\hline & Diarrhea & & & & & & & & & & & & \\
\hline & Yes & 45.45 & 21.05 & 15.79 & 18.18 & 5.82 & $0.1208^{\mathrm{ns}}$ & 53.85 & 32.00 & 18.18 & 0.00 & 10.06 & $0.0180^{*}$ \\
\hline & None & 54.55 & 78.95 & 84.21 & 81.82 & & & 46.15 & 68.00 & 81.82 & 100.00 & & \\
\hline & $\begin{array}{l}\text { Contagious } \\
\text { ecthyma }\end{array}$ & & & & & & & & & & & & \\
\hline & Yes & 0.00 & 0.00 & 5.26 & 0.00 & 2.78 & $0.4275^{\mathrm{ns}}$ & 0.00 & 0.00 & 4.55 & 0.00 & 2.26 & $0.5204^{\mathrm{ns}}$ \\
\hline & None & 100.00 & 100.00 & 94.74 & 100.00 & & & 100.00 & 100.00 & 95.45 & 100.00 & & \\
\hline & Footrot & & & & & & & & & & & & \\
\hline & Yes & 0.00 & 10.53 & 0.00 & 0.00 & 5.63 & $0.1309^{n s}$ & 0.00 & 4.00 & 0.00 & 9.09 & 2.72 & $0.4362^{\mathrm{ns}}$ \\
\hline & None & 100.00 & 89.47 & 100.00 & 100.00 & & & 100.00 & 96.00 & 100.00 & 90.91 & & \\
\hline
\end{tabular}


Table 2

Prevalence of mechanical factors contributing to morbidity in goat kids according to climatic season and age group

\begin{tabular}{|c|c|c|c|c|c|c|c|c|c|c|c|c|c|}
\hline & \multirow{2}{*}{$\begin{array}{l}\text { Type of } \\
\text { ailment }\end{array}$} & \multicolumn{4}{|l|}{ Season } & \multirow{2}{*}{$\begin{array}{l}\chi^{2} \\
\text { value }\end{array}$} & \multirow[t]{2}{*}{ P-value } & \multicolumn{4}{|c|}{ Age group (days) } & \multirow{2}{*}{$\begin{array}{l}\chi^{2} \\
\text { value }\end{array}$} & \multirow[t]{2}{*}{ P-value } \\
\hline & & $\begin{array}{l}\text { post- } \\
\text { rainy }\end{array}$ & $\begin{array}{l}\text { cold- } \\
\text { dry }\end{array}$ & $\begin{array}{l}\text { hot- } \\
\text { dry }\end{array}$ & $\begin{array}{l}\text { hot- } \\
\text { wet }\end{array}$ & & & $0-45$ & $\begin{array}{l}46- \\
90\end{array}$ & $\begin{array}{l}91- \\
135\end{array}$ & $<136$ & & \\
\hline \multirow[t]{6}{*}{$\begin{array}{l}\text { Year- } \\
1\end{array}$} & $\begin{array}{l}\text { Predatory } \\
\text { attacks }\end{array}$ & & & & & & & & & & & & \\
\hline & Yes & 0.00 & 0.00 & 15.15 & 12.50 & \multirow[t]{2}{*}{13.12} & \multirow[t]{2}{*}{$0.0044^{\star \star}$} & 3.33 & 3.13 & 5.77 & 10.00 & \multirow[t]{2}{*}{1.78} & \multirow[t]{2}{*}{$0.6200^{\text {ns }}$} \\
\hline & None & 100.00 & 100.00 & 84.85 & 87.50 & & & 96.67 & 96.88 & 94.23 & 90.00 & & \\
\hline & \multicolumn{13}{|l|}{$\begin{array}{l}\text { Knocked by } \\
\text { cars }\end{array}$} \\
\hline & Yes & 21.43 & 11.11 & 9.09 & 8.33 & \multirow[t]{2}{*}{3.64} & \multirow[t]{2}{*}{$0.3034^{\mathrm{ns}}$} & 20.00 & 25.00 & 7.69 & 3.33 & \multirow[t]{2}{*}{9.03} & \multirow[t]{2}{*}{$0.0289^{*}$} \\
\hline & None & 78.57 & 88.89 & 90.91 & 91.67 & & & 80.00 & 75.00 & 92.31 & 96.67 & & \\
\hline \multirow[t]{6}{*}{$\begin{array}{l}\text { Year- } \\
2\end{array}$} & $\begin{array}{l}\text { Predatory } \\
\text { attacks }\end{array}$ & & & & & & & & & & & & \\
\hline & Yes & 31.82 & 10.53 & 21.05 & 9.09 & \multirow[t]{2}{*}{3.86} & \multirow[t]{2}{*}{$0.2776^{\mathrm{ns}}$} & 30.77 & 28.00 & 13.64 & 0.00 & \multirow[t]{2}{*}{5.30} & \multirow[t]{2}{*}{$0.1510^{\mathrm{ns}}$} \\
\hline & None & 68.18 & 89.47 & 78.95 & 90.91 & & & 69.23 & 72.00 & 86.36 & 100.00 & & \\
\hline & \multicolumn{13}{|l|}{$\begin{array}{l}\text { Knocked by } \\
\text { cars }\end{array}$} \\
\hline & Yes & 13.64 & 15.79 & 10.53 & 9.09 & \multirow[t]{2}{*}{0.39} & \multirow[t]{2}{*}{$0.9419^{\text {ns }}$} & 15.38 & 20.00 & 9.09 & 0.00 & \multirow[t]{2}{*}{3.15} & \multirow[t]{2}{*}{$0.3691^{\mathrm{ns}}$} \\
\hline & None & 86.36 & 84.21 & 89.47 & 90.91 & & & 84.62 & 80.00 & 90.91 & 100.00 & & \\
\hline
\end{tabular}

Kids from all other age groups were at higher $(\mathrm{P}=0.0080)$ risk of dying through gastro-intestinal problems than those in younger age group ( 0 -45 days). In year-2 of the trial, gastro-intestinal problems were insignificantly low irrespective of the climatic season $(P=0.4254)$ and age group $(P=0.2325)$. Year-1 results show that high $(\mathrm{P}=0.0003)$ proportion of kids belonging to the two age groups ( $0-45$ days and $46-90$ days) died due to pneumonia irrespective of the season. However, year-2 prevalence of pneumonia insignificantly declined in both age groups $(P=0.2325)$ and season $(P=0.2577)$. Both year- 1 $(P=0.0042)$ and year-2 $(P=0.0014)$ results indicate that kids belonging to age groups $(91-135$ days $)$ and those older than 136 days were likely to die due to external wounds irrespective of the season. Deaths due to heart water were reported in year- $1(P=<0.0001)$ and year-2 $(P=0.0058)$, with high proportions recorded in hot-wet and hot-dry seasons. Respectively, high proportion $(P=<0.0001, P=0.0006)$ of kids from the two age groups ( $91-135$ days and those older than 136 days) died due to heartwater irrespective of the trial period. Obtained results in year- $1(P=0.0058)$ and year-2 ( $P=0.0013)$ show that high proportion of deaths due to hypothermia only occurred in cold-dry season than in other three climatic seasons. During year-2, high death $(P=0.0067)$ rate due to hypothermia was observed in kids less than 40 days old than those in other age groups. Inspite the insignificant level noted in the current trial, starvation was only prevalent during cold-dry season than in other climatic seasons, with kids less than 40 days old as the most victimised age group compare to older age groups. Table 4 summarizes the reproductive losses contributing to kid mortality rates in the present study. Dystocia cases were insignificantly reported throughout the trial period irrespective of the season and period of the trial. However, year- $1(P=0.0080)$ and year- 2 $(P=0.0078)$ results noted that dystocia cases only occurred in does giving birth for the first time than the multiparous goats. Obtained results in year- 1 revealed that only does $(P=<0.0001)$ in their first parity gave birth to stillborn kids irrespective of the season. Still births were insignificantly reported in primiporous does in year-2 irrespective of the climatic season. Only does in in their first parity experienced abortion cases in year- 1 . However, year- 2 results revealed that both climatic season $(P=0.0101)$ and parity of the doe $(P=0.0011)$ had an influence on abortion cases recorded in the current study, with primiporous does as the only victim.

\section{Discussion}

The current work recorded an extremely high kid mortality rate in the first year of the trial while this death rate significantly declined in year-2 of the research period. High death rate of kids in year- 1 could be attributed to the remoteness of the study areas from the agricultural institutions offering animal health and other extension services, lack of awareness and reluctance to seek veterinary services, and too large herds that lead to poor attention of individual animals. In addition, farmers in the participating villages were observed to have accepted the death of kids as a normal practice due to ongoing mortality rates every year. Results from the present study agree favourably with those obtained by Sebei et al. (2004) who reported a mortality rate of $46.51 \%$ in Mpumalanga Province of South Africa. To avoid further disappointment accompanied by various causes of kid mortalities, communal farmers rarely count the young stock in their goat flocks (Dube et al., 2016). Efforts to develop disease control strategies to reduce mortality remain a considerable necessity in communal farming areas (Bhattarai, 2021; Idamokoro \& Masika, 2017). The present study is the first to devise and implement strategies to control diseases and climate change-related deaths in communally managed goat flocks of South Africa. 
Table 3

Prevalence of infectious diseases and management factors contributing to mortality in goat kids according to season and age group

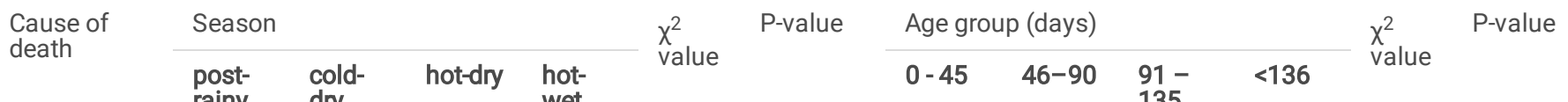

$\begin{array}{ll}\text { Year } & \text { GIT } \\ 1 & \text { problems }\end{array}$

\begin{tabular}{|c|c|c|c|c|c|c|c|c|c|c|c|c|}
\hline Yes & 0.00 & 25.00 & 16.67 & 30.00 & 14.41 & $0.0024^{\star \star}$ & 18.75 & 0.00 & 28.13 & 17.86 & 11.81 & $0.0080^{* \star}$ \\
\hline
\end{tabular}

Pneumonia

$\begin{array}{lllllllllllll}\text { Yes } & 15.22 & 13.89 & 10.00 & 10.00 & 0.63 & 0.8904^{\mathrm{ns}} & 34.38 & 7.50 & 9.38 & 0.00 & 18.70 & 0.0003^{\star *} \\ \text { None } & 84.78 & 86.11 & 90.00 & 90.00 & & & 65.63 & 92.50 & 90.63 & 100.00 & \end{array}$

External

wound

\begin{tabular}{|c|c|c|c|c|c|c|c|c|c|c|c|c|}
\hline Yes & 4.35 & 13.89 & 10.00 & 15.00 & \multirow[t]{2}{*}{2.83} & \multirow[t]{2}{*}{$0.4189^{n s}$} & 21.88 & 17.86 & 0.00 & 3.13 & \multirow[t]{2}{*}{13.23} & \multirow[t]{2}{*}{$0.0042^{* \star}$} \\
\hline None & 95.65 & 86.11 & 90.00 & 85.00 & & & 78.13 & 82.14 & 100.00 & 96.33 & & \\
\hline \multicolumn{13}{|c|}{ Heartwater } \\
\hline Yes & 0.00 & 2.78 & 40.00 & 45.00 & \multirow[t]{2}{*}{37.52} & \multirow[t]{2}{*}{$<0.0001^{\star \star}$} & 0.00 & 0.00 & 31.25 & 42.86 & \multirow[t]{2}{*}{33.13} & \multirow[t]{2}{*}{$<0.0001^{\star \star}$} \\
\hline No & 100.00 & 97.22 & 60.00 & 55.00 & & & 100.00 & 100.00 & 68.75 & 68.75 & & \\
\hline \multicolumn{13}{|c|}{ Hypothermia } \\
\hline Yes & 5.56 & 19.57 & 0.00 & 0.00 & \multirow[t]{2}{*}{12.51} & \multirow[t]{2}{*}{$0.0058^{\star \star}$} & 15.63 & 7.50 & 3.13 & 7.14 & \multirow[t]{2}{*}{3.45} & \multirow[t]{2}{*}{$0.3270^{\text {ns }}$} \\
\hline None & 94.44 & 80.43 & 100.00 & 100.00 & & & 84.38 & 92.50 & 96.88 & 92.86 & & \\
\hline \multicolumn{13}{|c|}{ Starvation } \\
\hline Yes & 9.52 & 18.75 & 0.00 & 0.00 & 4.72 & $0.1937^{\mathrm{ns}}$ & 15.38 & 7.69 & 10.00 & 0.00 & 2.45 & $0.4850^{\mathrm{ns}}$ \\
\hline
\end{tabular}

Year- GIT

2 problems

\begin{tabular}{|c|c|c|c|c|c|c|c|c|c|c|c|c|}
\hline Yes & 0.00 & 14.29 & 15.38 & 16.67 & 2.79 & $0.4254^{\mathrm{ns}}$ & 7.69 & 23.08 & 15.00 & 0.00 & 4.28 & $0.2325^{\mathrm{ns}}$ \\
\hline None & 100.00 & 85.71 & 84.62 & 83.33 & & & 92.31 & 76.92 & 85.00 & 100.00 & & \\
\hline
\end{tabular}

Pneumonia

\begin{tabular}{|c|c|c|c|c|c|c|c|c|c|c|c|c|}
\hline Yes & 0.00 & 9.52 & 0.00 & 0.00 & \multirow[t]{2}{*}{4.03} & \multirow[t]{2}{*}{$0.2577^{\mathrm{ns}}$} & 0.00 & 7.69 & 0.00 & 6.25 & \multirow[t]{2}{*}{2.40} & \multirow[t]{2}{*}{$0.4937^{\text {ns }}$} \\
\hline None & 100.00 & 90.48 & 100.00 & 100.00 & & & 100.00 & 92.31 & 100.00 & 93.75 & & \\
\hline \multicolumn{13}{|c|}{$\begin{array}{l}\text { External } \\
\text { wound }\end{array}$} \\
\hline Yes & 18.75 & 23.81 & 30.77 & 33.33 & \multirow[t]{2}{*}{0.98} & \multirow[t]{2}{*}{$0.8056^{\mathrm{ns}}$} & 26.92 & 22.73 & 3.77 & 6,67 & \multirow[t]{2}{*}{15.59} & \multirow[t]{2}{*}{$0.0014^{\star *}$} \\
\hline None & 81.25 & 76.19 & 69.23 & 66.67 & & & 73.08 & 17.53 & 96.33 & 93.33 & & \\
\hline Yes & 28.57 & 0.00 & 53.85 & 50.00 & \multirow[t]{2}{*}{12.52} & \multirow[t]{2}{*}{$0.0058^{\star *}$} & 0.00 & 7.69 & 40.00 & 62.50 & \multirow[t]{2}{*}{17.43} & \multirow[t]{2}{*}{$0.0006^{\star \star}$} \\
\hline No & 71.43 & 100.00 & 46.15 & 50.00 & & & 100.00 & 92.31 & 60.00 & 37.50 & & \\
\hline \multicolumn{13}{|c|}{ Hypothermia } \\
\hline Yes & 0.00 & 31.25 & 100.00 & 0.00 & 15.64 & $0.0013^{\star \star}$ & 30.77 & 7.69 & 0.00 & 0.00 & 12.20 & $0.0067^{\star \star}$ \\
\hline Yes & 9.52 & 18.75 & 0.00 & 0.00 & 4.72 & $0.1937^{\mathrm{ns}}$ & 15.38 & 7.69 & 10.00 & 0.00 & 2.45 & $0.4850^{\text {ns }}$ \\
\hline
\end{tabular}




\begin{tabular}{|c|c|c|c|c|c|c|c|c|}
\hline None & 90.48 & 81.25 & 100.00 & 100.00 & 84.62 & 92.31 & 90.00 & 100.00 \\
\hline
\end{tabular}

Table 4

Prevalence of reproductive fatalities contributing to mortality rate of goat kids according to climatic season and age group

\begin{tabular}{|c|c|c|c|c|c|c|c|c|c|c|c|c|c|}
\hline & \multirow{2}{*}{$\begin{array}{l}\text { Cause of } \\
\text { death }\end{array}$} & \multicolumn{4}{|c|}{ Season } & \multirow{2}{*}{$\begin{array}{l}\chi^{2} \\
\text { value }\end{array}$} & \multirow[t]{2}{*}{ P-value } & \multicolumn{4}{|l|}{ Parity } & \multirow{2}{*}{$\begin{array}{l}\chi^{2} \\
\text { value }\end{array}$} & \multirow[t]{2}{*}{ P-value } \\
\hline & & $\begin{array}{l}\text { post- } \\
\text { rainy }\end{array}$ & $\begin{array}{l}\text { cold- } \\
\text { dry }\end{array}$ & hot-dry & $\begin{array}{l}\text { hot- } \\
\text { wet }\end{array}$ & & & $1 \mathrm{st}$ & 2nd & $3 r d$ & 4th & & \\
\hline \multirow{9}{*}{$\begin{array}{l}\text { Year- } \\
1\end{array}$} & Dystocia & & & & & & & & & & & & \\
\hline & Yes & 8.33 & 13.04 & 6.67 & 0.00 & \multirow[t]{2}{*}{3.26} & \multirow{2}{*}{$0.3528^{\text {ns }}$} & 27.50 & 0.00 & 0.00 & 0.00 & \multirow[t]{2}{*}{27.60} & \multirow[t]{2}{*}{$<0.0001^{\star \star}$} \\
\hline & None & 91.67 & 86.96 & 93.33 & 100.00 & & & 72.50 & 100.00 & 100.00 & 100.00 & & \\
\hline & \multicolumn{13}{|l|}{ Stillbirth } \\
\hline & Yes & 8.33 & 17.39 & 3.33 & 0.00 & \multirow[t]{2}{*}{7.06} & \multirow[t]{2}{*}{$0.0699^{\text {ns }}$} & 30.00 & 0.00 & 0.00 & 0.00 & \multirow[t]{2}{*}{30.36} & \multirow[t]{2}{*}{$<0.0001^{\star \star}$} \\
\hline & None & 91.67 & 82.61 & 96.67 & 100.00 & & & 70.00 & 100.00 & 100.00 & 100.00 & & \\
\hline & \multicolumn{13}{|l|}{ Abortion } \\
\hline & Yes & 2.78 & 13.04 & 3.33 & 0.00 & \multirow[t]{2}{*}{6.30} & \multirow[t]{2}{*}{$0.0977^{\mathrm{ns}}$} & 20.00 & 0.00 & 0.00 & 0.00 & \multirow[t]{2}{*}{19.59} & \multirow[t]{2}{*}{$0.0002^{\star *}$} \\
\hline & None & 97.22 & 86.96 & 96.67 & 100.00 & & & 80.00 & 100.00 & 100.00 & 100.00 & & \\
\hline \multirow{9}{*}{$\begin{array}{l}\text { Year- } \\
2\end{array}$} & Dystocia & & & & & & & & & & & & \\
\hline & Yes & 4.76 & 12.50 & 0.00 & 0.000 & \multirow[t]{2}{*}{3.31} & \multirow{2}{*}{$0.3461^{\mathrm{ns}}$} & 23.08 & 0.00 & 0.00 & 0.00 & \multirow[t]{2}{*}{11.88} & \multirow[t]{2}{*}{$0.0078 * \star$} \\
\hline & None & 95.24 & 87.50 & 100.00 & 100.00 & & & 76.92 & 100.00 & 100.00 & 100.00 & & \\
\hline & \multicolumn{13}{|l|}{ Stillbirth } \\
\hline & Yes & 4.76 & 0.00 & 0.00 & 0.00 & \multirow[t]{2}{*}{1.98} & \multirow[t]{2}{*}{$0.5757^{\mathrm{ns}}$} & 7.69 & 0.00 & 0.00 & 0.00 & \multirow[t]{2}{*}{3.83} & \multirow[t]{2}{*}{$0.2803^{\text {ns }}$} \\
\hline & None & 95.24 & 100.00 & 100.00 & 100.00 & & & 92.31 & 100.00 & 100.00 & 100.00 & & \\
\hline & Abortion & & & & & & & & & & & & \\
\hline & Yes & 3.51 & 14.52 & 2.33 & 0.00 & 11.33 & $0.0101^{*}$ & 30.77 & 0.00 & 0.00 & 0.00 & 16.12 & $0.0011^{\star *}$ \\
\hline & None & 96.49 & 85.48 & 97.67 & 100.00 & & & 69.23 & 100.00 & 100.00 & 100.00 & & \\
\hline
\end{tabular}

Note: ${ }^{*}=$ Significant at $\mathrm{p}<0.05 ; * \star=$ Significant at $\mathrm{p}<0.01 ; \mathrm{ns}=$ not significant.

Consistent support from agricultural institutions could be a great start in facilitating and mentoring communal farmers as observed in the current study where mortality rate was reduced within one year of the follow-up period. Causes of mortality have not been well documented in communally managed goats in South Africa. A high death rate due to unknown causes was recorded by Slayi et al. (2014) in communal goat flocks in the Eastern Cape Province. Several health problems contributing to mortality were highlighted in the current study. Among those include helminthosis, diarrhea, tick loads, contagious ecthyma and Footrot. These disease conditions have also been reported in many countries worldwide (Arsoy, 2020; Talukder et al., 2020). Helminthosis in the current study was mostly prevalent in all the climatic seasons except in cold-dry seasons. An explanation of this could be that the lifecycle of internal parasites requires warmer temperatures and moist conditions to successfully grow and reproduce (Slayi et al., 2014). Such conditions are lacking in the cold-dry season, making to unsuitable for the growth of the parasites thus, they resort to delaying their growth until favourable conditions arise later in the year. This growth delaying mechanism by various species of internal parasites is sometimes known as hypobiosis (Abraham et al., 2018; Adebambo et al., 2021). Only younger stock less than 45 days were not victims of helminthosis. Prevalence of helminthosis in older kids may be attributed to feeding on infected pastures in communal grazing areas. Undetectable helminth levels in younger kids could be attributed to the fact that the kids are still below three months and the life cycle period for internal parasite take three to six month to mature, hence the absence is reasonable (Fthenakis \& Papadopoulos, 2018). The low prevalence of helminthosis in older kids after the intervention of the research team could be due to a deworming programme carried out every beginning of the season.

Prevalence of diarrhea was observed in all the kids irrespective of the age group and climatic season. This may have been caused by bacteria, viruses, dietary factors, and gastrointestinal parasites (Donkin \& Boyazoglu, 2004; Yasmin et al., 2020). Death and sickness due to diarrhea were reported in earlier works (Faruque et al., 2017; Oyeyemi \& Akusu, 2021). An improvement in hygiene and careful husbandry of the kids in year-2 made a great difference in reducing the effects of diarrhea, but it remained the most important problem in the herd. The prevalence of ticks observed in the current study irrespective of age may be due to browsing in heavily infested communal grazing areas and poor shelter hygiene. The low tick infestation in kids less than 45 days may be due to total confinement since they are not yet allowed to go together with their does. The practice of allowing manure to accumulate in animal houses for use in crop field fertilisation may have resulted in increased warmth and humidity that favoured the proliferation of the ticks (Sebei et al., 2004). The low prevalence of ticks in year-2 could be attributed to adoption of fortnight dipping schedule as advised by the research 
team. On the other hand, the insignificant existence of tick loads could be that the flocks were not isolated from other communal flocks, thus results to acquisition of infestation from other flocks (Fthenakis \& Papadopoulos, 2018; Robertson et al., 2020). Kids continued to acquire injuries due to predatory attacks throughout the year, and this could happen because goats from the studied villages were left to graze unsupervised. Findings from this study agree with those reported by Slayi et al. (2014), who also noted that younger stock in the studied area were at higher risk on getting preyed by the predators like jackals and hunting dogs. After the farmers hired some labour to supervise their goats in the veld through advices from the research team, predatory attacks were minimal, but remain a matter of concern. Younger kids were at higher risk of getting knocked by cars and farmers were encouraged to house their kids or put them in a fenced garden to provide protection from stray dogs and cars. The causes of mortalities observed in the current study are similar to those reported in South Africa and elsewhere in Africa (Bélanger-Naud et al., 2021; El-Abid \& Abu Nikhaila, 2009). The season was noted to have an effect on the death of kids due to gastrointestinal problems. The high death rate of the older kids due to gastro-intestinal problems could be associated with heavy endo-parasitic load and prevalence of coccidia species due to unhygienic housing conditions and grazing on helminth infested pastures. Death due to coccidiosis is highly prevalent in younger stock since they do not have a fully developed immunity (Bélanger-Naud et al., 2021). This could be the increased death rate due gastrointestinal problems in younger kids since they were confined in wet and dirty kraals. Low mortality rate in year- 2 could be directed to efforts made by the research team to regularly advise farmers to clean the housing conditions and to give animals sanitary drinking water at all times. It was noted that in year- 1 of the follow-up period, a high proportion of kids died due to pneumonia in their first 45 days of life. Similar findings were reported by Snyman (2010) who also noted high death rate of kids due to pneumonia in the first 35 days after birth. In most instances pneumonia and coccidiosis occur altogether and the causative agent for pneumonia has been studied in many countries. Pneumonia occurs when infectious and non-infectious agents cause the lungs of goats to become inflamed (Bhattarai, 2021; Vandana et al., 2015). The most frequent causes of respiratory infection and death are Pasteurella multocida or Mannheimia haemolytica (previously called Pasteurella haemolytica) (Alula et al., 2014; Diriba \& Kebede, 2020). Heath complications from these pathogens are associated with poor management practices, such as overcrowded pens, poor housing conditions and other stressful conditions increasing susceptibility of the kids to P. multocida and M. haemolytica pneumonias (Arsoy, 2020; Yasmin et al., 2020). In most cases the pneumonia diagnosed after two months could be a complication arising from the weakening effects of earlier gastrointestinal problems. A timely treatment with diclazural was usually effective in stopping the diarrhoea, but by then much damage had already been done. Affected kids usually died, if not from diarrhoea, then from pneumonia. Those that were saved remained stunted. Preventative measures included the addition of an ionophore to the feed, either monensin or lasalocid. This could be the reason for the low death rate in year-2 after adopting intervention strategies from the research team.

It was noted that kids less than 90 days of age died due to acquired injuries caused by predatory attacks while illegally went out to browse on communal grazing lands with their does. Findings from this study agree with those reported by Ebozoje \& Ngere (2021) who recorded a high death rate of kids due to predation. The reason for this could be that kids less than six weeks were supposedly disallowed to go and graze with their mothers unsupervised. This negligence from farmers exposed the kids to higher risks of being attacked by predators. In general, this system was inefficient, although similar to the method used by farmers in other developing countries (Diriba \& Kebede, 2020). Labour difficulties due to financial constraints and social conflicts within the villages at the time of conducting the study were cited as the main reason for endless predatory attacks in year-2 since the kids continued to graze without supervision of the herder. Season was defined to have a major influence on death rate due to Heartwater in both year-1 and year-2. Death due to Heartwater coincided with the increased tick prevalence reported earlier in the study as most fatalities occurred during the year's hot and wet climatic seasons. Heartwater is transferred to goats through an infected tick bite (Mhlanga et al., 2018). Amblyomma hebraeum is the tick species transmitting the Heartwater in goats (Slayi et al., 2014). The seasonal occurrence of A. hebraeum has been studied before. It appears to be climate-dependent and varies throughout its distribution range (Vandana et al., 2015). The species has three-host life cycle, with larvae, nymphs and adults feeding on separate hosts (Debele et al., 2011). The adults are often visible in large numbers during warm-wet-summer months, larvae during colder, late autumn and winter months, and nymphs during winter and spring months (Rashidi et al., 2011). Finding from the present study agrees with those reported by Sebei et al. (2004) who reported an increase in Heartwater-related deaths in kids that are grazing with older stock in the veld. Communal grazing lands infested with Amblyomma tick species are the predisposing factors to Heartwater fatalities in young stock, and implementing a holistic grazing management approach is highly recommended. Death due to hypothermia remained a problem of interest in both year-1 and 2 . Kids in their first 45 days of life were at greater risk of being killed by exposure to extreme cold conditions in the area. This observation agrees with previous results by Alula et al. (2014) who reported that climate-related problems always pose a greater risk to young stock kept under rural farming conditions. An improved housing infrastructure is necessity for better survival of young kids in resource-constrained communities. Starvation-related deaths to kids less than 45 days of age was a problem that farmers rarely considered. Most of these deaths were experienced during cold-dry months of the year. Feed shortages during winter months resulted in poor mothering ability through the refusal of infant kids to suckle milk from their dams. This observation is in agreement with results obtained by Donkin \& Boyazoglu (2004). Partial supplementation of pregnant and nursing does during dry months is highly encouraged.

Dystocia remained a problem in both year-1 and 2, with does in their first parity as the only victim. Causes of dystocia can range from foetal factors such as large foetus or abnormal positioning (Adebambo et al., 2021). Other researchers highlighted maternal factors as the predisposing factor to dystocia (Hasan et al., 2015; Robertson et al., 2020). These factors include narrowed birth canal, lack of contractions, or exhaustions for prolonged contractions (Moni \& Samad, 2019). Proper supervision to first time does around parturition is highly advised to ease the problem. Stillborn kids were a problem to first time does during year-1. Stillborn kids are usually exposed to infections like toxoplasmosis, brucellosis, chlamydiosis or leptospirosis (Chauhan et al., 2019). Kids suffering from these infections are normally born weak and die shortly after birth. Infections are often a result of poor farm hygiene or poor biosecurity. Efforts to improve sanitary conditions could be commended for the low enrolment of stillborn cases in year-2. Abortion cases were mostly experienced by goats who are in their first parity during cold-dry season. The most important cause of abortion after day 90 of

Page $10 / 13$ 
pregnancy is a nutritional energy deficiency caused by lack of good quality forage (Abraham et al., 2018). Pregnant goats from the respective villages were not supplemented even though there were feed shortages during dry months. Supplementation of pregnant goats and those in the first parity is highly emphasised.

\section{Conclusion}

The results of this study thus show that management factors such as confinement in houses, grazing systems and house hygiene, to a variable extent, influence the prevalence of diseases and other climate-change related deaths in village goat kids. In response to the results from this baseline survey, a small community engagement intervention was initiated through a research team. Farmers were provided with some veterinary drugs and extension advice. Kids born during the pilot intervention trial were monitored for 12 months. A decline in kid mortalities was observed (from 56.17-22.38\%), indicating that the approach was a moderate success. However, is it scalable and affordably so? This community engagement programme requires further investigation prior to implementing the intervention model at a broader level. So does the possibility that much could be gained by blending conventional drugs with traditional treatments to improve the survival rate of kids under village farming conditions.

\section{Declarations}

\section{Author contributions}

Conceptualization, MS and LZ.; Methodology, MS; Data curation, TLT and MS.; writing-original draft preparation, MS.; writing-review and editing, LZ. IFJ and TLT. All authors have read and agreed to the published version of the manuscript.

\section{Funding}

This research was funded by National Research Foundation, grant number TS64 (UID: 99787).

\section{Institutional Review Board Statement}

Ethical review and approval was granted for this study through the University of Fort Hare Research and Ethics committee.

\section{Informed consent statement}

Not applicable

\section{Data availability Statement}

The data presented in this study is contained within the article.

\section{Conflicts of interest}

The authors declare no conflict of interest.

\section{References}

1. Abiola, S. S., \& Onwuka, C. F. I. (2021). Reproductive performance of West African dwarf sheep and goats at village level in Ogun State, Nigeria. Nigerian Journal of Animal Production, 25(1). https://doi.org/10.51791/njap.v25i1.2246

2. Abraham, H., Gizaw, S., \& Urge, M. (2018). Identification of breeding objectives for Begait goat in western Tigray, North Ethiopia. Tropical Animal Health and Production, 50(8). https://doi.org/10.1007/s11250-018-1640-5

3. Adebambo, O. A., Samuel, A. O., \& Onakade, A. D. (2021). Causes of variation in reproductive performance of West African dwarf goat. Nigerian Journal of Animal Production, 21. https://doi.org/10.51791/njap.v21i1.1084

4. Alemnew, E., Yitagesu, E., Goshme, S., \& Aydefruhim, D. (2020). Retrospective study on kid mortality and associated risk factors of kid survival of newly introduced Boer goat breed in North Shewa Ethiopia. Livestock Research for Rural Development, 32(7).

5. Alula, P., Kassaye, A., \& Berhanu, S. (2014). Pre-weaning kid mortality in Adamitulu Jedokombolcha District, Mid Rift Valley, Ethiopia. Journal of Veterinary Medicine and Animal Health, 6(1). https://doi.org/10.5897/jvmah13.0211

6. Arsoy, D. (2020). Herd management and welfare assessment of dairy goat farms in Northern Cyprus by using breeding, health, reproduction, and biosecurity indicators. Tropical Animal Health and Production, 52(1). https://doi.org/10.1007/s11250-019-01990-3 
7. Bélanger-Naud, S., Cinq-Mars, D., Julien, C., Arsenault, J., Buczinski, S., Lévesque, J., \& Vasseur, E. (2021). A survey of dairy goat kid-rearing practices on Canadian farms and their associations with self-reported farm performance. Journal of Dairy Science. https://doi.org/10.3168/jds.2020-18663

8. Bhattarai, N. (2021). Effect of non-genetic factors on prolificacy and pre-weaning kid mortality of Khari goats in Nawalpur, Nepal. Journal of Agriculture and Natural Resources, 4(1). https://doi.org/10.3126/janr.v4i1.33230

9. Chauhan, I. S., Misra, S. S., Kumar, A., \& Gowane, G. R. (2019). Survival analysis of mortality in pre-weaning kids of Sirohi goat. Animal, 13(12). https://doi.org/10.1017/S1751731119001617

10. Debele, G., Duguma, M., \& Hundessa, F. (2011). Effect of different factors on mortality rate of Arsi- Bale kids in mid rift valley of Ethiopia. Global Veterinaria, 6(1).

11. Diriba, L., \& Kebede, T. (2020). Assessments of husbandry practices, major constraints and opportunities of sheep and goat production in Sinana district, bale zone, Ethiopia. 1 International Journal of Veterinary Sciences and Animal Husbandry, 5(3).

12. Donkin, E. F., \& Boyazoglu, P. A. (2004). Diseases and mortality of goat kids in a South African milk goat herd. South African Journal of Animal Sciences, 34(5SUPPL.1).

13. Dube, K., Muchenje, V., \& Mupangwa, J. F. (2016). Inbreeding depression and simulation of production potential of the communally raised indigenous Xhosa lop eared goats. Small Ruminant Research, 144. https://doi.org/10.1016/j.smallrumres.2016.09.015

14. Ebozoje, M. O., \& Ngere, L. O. (2021). Incidence of preweaning mortality in West African dwarf goats and their red sokoto halfbreds. Nigerian Journal of Animal Production, 22(1). https://doi.org/10.51791/njap.v22i1.2043

15. El-Abid, K. E. H., \& Abu Nikhaila, A. M. A. (2009). A study on some factors affecting mortality rates in Sudanese Nubian Kids. International Journal of Dairy Science, 4(2). https://doi.org/10.3923/ijds.2009.74.79

16. Faruque, M., Choudhury, M., Ritchil, C., Tabassum, F., Hashem, M., \& Bhuiyan, A. (2017). Assessment of performance and livelihood generated through community based goat production in Bangladesh. SAARC Journal of Agriculture, 14(2). https://doi.org/10.3329/sja.v14i2.31241

17. Fthenakis, G. C., \& Papadopoulos, E. (2018). Impact of parasitism in goat production. Small Ruminant Research, 163. https://doi.org/10.1016/j.smallrumres.2017.04.001

18. Hasan, M. J., Ahmed, J. U., Alam, M. M., Mojumder, M. L. O., \& Ali, M. S. (2015). Reproductive performance of Black Bengal goat under semiintensive and extensive condition in Rajshahi district of Bangladesh. Asian Journal of Medical and Biological Research, 1(1). https://doi.org/10.3329/ajmbr.v1i1.25494

19. Idamokoro, E. M., \& Masika, P. J. (2017). Peri- and post-parturient consequences of maternal undernutrition of free ranging does: A review. In Livestock Research for Rural Development (Vol. 29, Issue 10).

20. Khandoker, M., Afini, N., \& Azwan, A. (2018). Productive and reproductive performance of Saanen goat at AZZahra farm of Sandakan in Malaysia. Bangladesh Journal of Animal Science, 47(1). https://doi.org/10.3329/bjas.v47i1.39395

21. Mhlanga, T. T., Mutibvu, T., \& Mbiriri, D. T. (2018). Goat flock productivity under smallholder farmer management in Zimbabwe. Small Ruminant Research, 164. https://doi.org/10.1016/j.smallrumres.2018.05.010

22. Moni, M. I. Z., \& Samad, M. A. (2019). Evaluation of productive and reproductive performances of Black Bengal goats in Rajshahi government goat development farm in Bangladesh. Journal of Veterinary Medical and One Health Research, 1(2). https://doi.org/10.36111/jvmohr.2019.1(2).0012

23. Oyeyemi, M. O., \& Akusu, M. O. (2021). Retrospective study on some diseases causing mortality in West African Dwarf (Fouta djallon) goats during the first year of life: an eight-year study. Nigerian Journal of Animal Production, 32(1). https://doi.org/10.51791/njap.v32i1.1062

24. Perumal, P., Kundu, A., Sunder, J., Kundu, M. S., Bhattacharya, D., Sujatha, T., \& De, A. K. (2019). Kidding pattern and mortality rate of indigenous local goat kids reared under semi-intensive system in Andaman and Nicobar Islands. Indian Journal of Animal Sciences, 89(6).

25. Rashidi, A., Bishop, S. C., \& Matika, O. (2011). Genetic parameter estimates for pre-weaning performance and reproduction traits in Markhoz goats. Small Ruminant Research, 100(2-3). https://doi.org/10.1016/j.smallrumres.2011.05.013

26. Robertson, S. M., Atkinson, T., Friend, M. A., Allworth, M. B., \& Refshauge, G. (2020). Reproductive performance in goats and causes of perinatal mortality: A review. Animal Production Science, 60(14). https://doi.org/10.1071/AN20161

27. Sebei, P. J., McCrindle, C. M. E., \& Webb, E. C. (2004). Factors influencing weaning percentages of indigenous goats on communal grazing. South African Journal of Animal Sciences, 34(5SUPPL.1).

28. Slayi, M., Maphosa, V., Fayemi, O. P., \& Mapfumo, L. (2014). Farmers' perceptions of goat kid mortality under communal farming in Eastern Cape, South Africa. Tropical Animal Health and Production, 46(7). https://doi.org/10.1007/s11250-014-0630-5

29. Snyman, M. A. (2010). Factors affecting pre-weaning kid mortality in South African Angora goats. South African Journal of Animal Sciences, 40(1). https://doi.org/10.4314/sajas.v40i1.54128

30. Talukder, M. A. I., Rahman, M. M., Alam, M. A., Hossain, M. A., \& Hemayet, M. A. (2020). Effects of genetic and environmental factors on productive performances of Hilly Brown Bengal goat at Naikhongchari. Journal of Bioscience and Agriculture Research, 26(02).

https://doi.org/10.18801/jbar.260220.268

31. Vandana, V., PALOD, J., SINGH, D. V., KUMAR, B., \& SINGH, S. K. (2015). Growth pattern and mortality rate of kids of pantja goat under farm condition. Veterinary Science Research Journal, 6(1). https://doi.org/10.15740/has/vsrj/6.1/32-35

32. Wachida, N., Ishor, A. W., Adi, D. S., Tughgba, T., \& Dawuda, P. M. (2018). Survey for Productive Performance of West African Dwarf (WAD) does and Savanna Brown Goat (SBG) does reared under traditional husbandry system. Nigerian Veterinary Journal, 39(2).

Page $12 / 13$ 
https://doi.org/10.4314/nvj.v39i2.1

33. Yasmin, F., Huque, K., Chowdhury, S., \& Miyan, M. (2020). Impact of goat population management strategies on goat meat production in Bangladesh. Bangladesh Journal of Livestock Research. https://doi.org/10.3329/bjlr.v0i0.45454

\section{Figures}

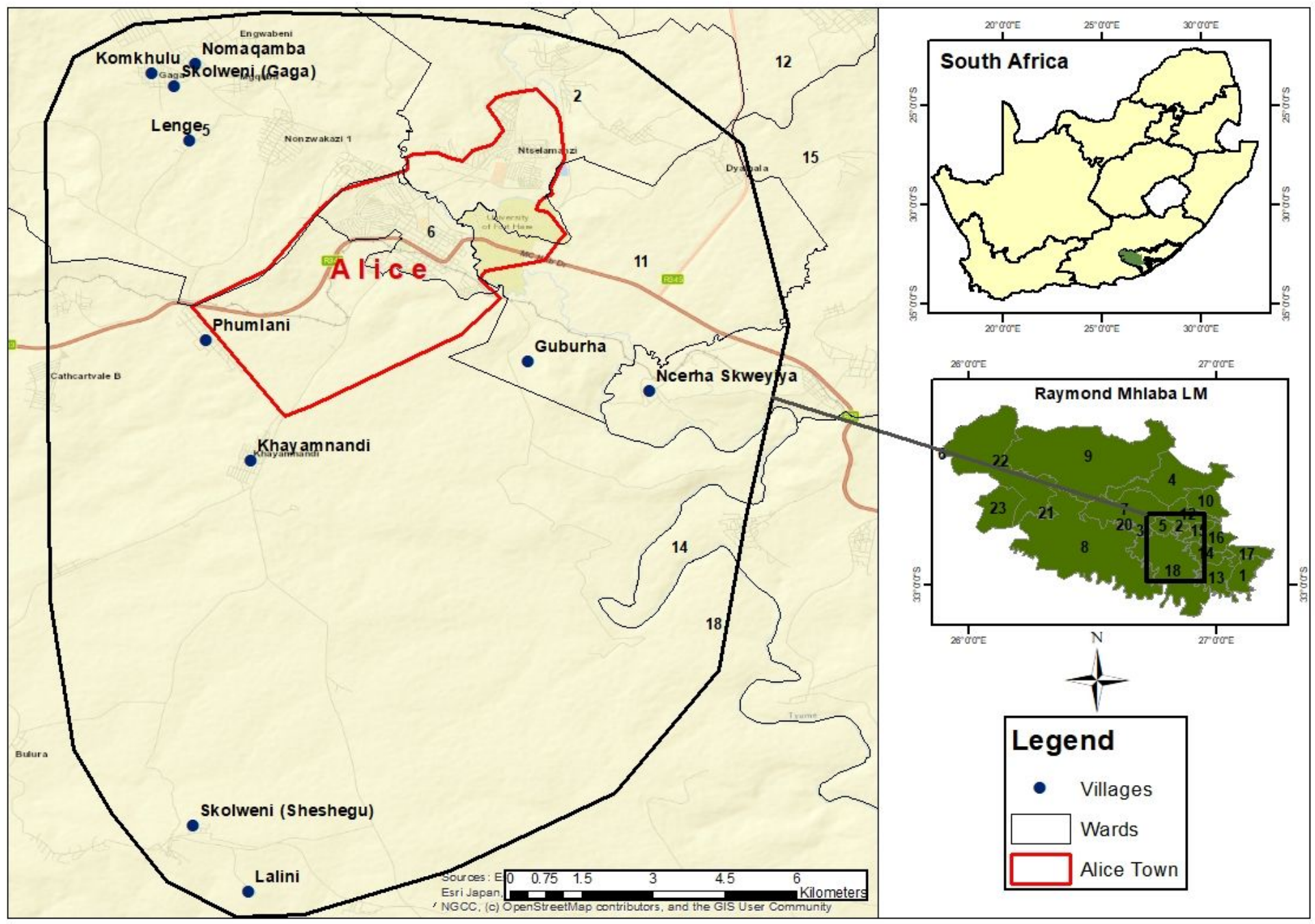

Figure 1

Geographic location of ten villages used study sites within Alice district under Raymond Mhlaba Local Municipality Source: Adapted from Google earth 